\title{
タンパク質ダイナミクス観測のための時間分解共鳴ラマン分光計開発
}

\author{
水野操，水谷泰久 \\ 大阪大学大学院 理学研究科 (广560-0043 大阪府豊中市待兼山町1-1)
}

\section{Development of Time-Resolved Resonance Raman Spectrometer for Observation of Protein Dynamics}

\author{
Misao MIZUNO and Yasuhisa MIZUTANI \\ Graduate School of Science, Osaka University, 1-1 Machikaneyama, Toyonaka, Osaka 560-0043
}

(Received April 20, 2009)

\begin{abstract}
Proteins function by changing their structures, and external stimuli facilitate the sequential change of specific structural sites. To understand the mechanism of protein functions, it is essential to clarify how external stimuli can bring about these site-specific structural changes. Time-resolved ultraviolet resonance Raman spectroscopy probes the structural dynamics of specific sites in protein structure by selectively enhancing the vibrational Raman bands assignable to aromatic amino acid side chains as well as polypeptide bonds. We have constructed a picosecond time-resolved ultraviolet resonance Raman spectrometer to observe ultrafast protein dynamics.
\end{abstract}

Key Words: Resonance Raman spectroscopy, Time-resolved spectroscopy, Protein dynamics

1. はじめに

タンパク質は, 安定な立体構造を保持しつつも柔らか く構造を変化させ，機能している。多くのタンパク質分 子には, 外部からの刺激を感知する部分と, 機能に直接 関わる部分が，それぞれ別々に存在している。たとえ ば，光刺激により機能を発揮する光センサータンパク質 は, 発色団とよばれる小分子の補欠分子族が光吸収し, 構造が変化する。この構造変化が引き金となり, 補欠分 子族から離れた部位にまで, 段階的な構造変化が伝播 し，活性が制御されると概念的に考えられている。 タン パク質が機能を発現する機構を理解するには, 分子構造 の決定が必要不可欠である。このためには，第一に，夕 ンパク質がどのような立体構造をしているのかを理解し なければならない．X線回折法やNMR分光法による立体 構造の決定が行われ, 多くのタンパク質の「静的」な構造 が明らかにされた。機構解明のためには，その次のス テップとして, どのように構造が変化し, 構造変化が伝 播するのか，「動的」な構造を明らかにしなければならな い.タンパク質は, サブピコ秒から秒までの幅広い時間 スケール，数ナノメートルから数百ナノメートルまでの 幅広い空間スケールにおよぶ, 複雑に連動した過程から なる構造ダイナミクスを示す。このようなダイナミクス を明らかにするためには, タンパク質中で逐次的に起こ る構造変化を, 部位ごと, 段階ごとに観測しなくてはな らない，筆者らは，時間分解共鳴ラマン分光法をもちい
て, タンパク質ダイナミクスに関する研究を行ってい る。本稿では, 共鳴ラマン分光法の特色と, タンパク質 ダイナミクスの観測を行うためのピコ秒時間分解紫外共 鳴ラマン分光計について解説する。 また, 研究結果の一 例として，イエロープロテインの光反応初期過程におけ る構造ダイナミクス観測を紹介する。

\section{2. 共鳴ラマン分光法}

ラマン分光法は，振動分光法の一種である．振動分光 法は, 結晶構造解析とは異なり, 分子中における各原子 の位置情報を直接的に得ることができない。しかし，振 動スペクトルに観測されるバンドの振動数や強度から, 化学結合の微小变化を鋭敏に検出できる特徵がある。た た，タンパク質のような高分子の振動スペクトルはその ままでは複雑すぎるため，個々の分子振動を区別して観 測し，構造解析を行うことは非常に困難である.

タンパク質分子中の個々の部位における構造変化を選 択的に観測するためには，共鳴ラマン効果を利用するこ とが有効である。共鳴ラマン効果は, ラマン散乱の励起 光 (プローブ光)の波長を分子の電子吸収に合わせること によって, 散乱光強度が $10^{4}-10^{6}$ 倍に増強される現象をさ す。散乱光の強度増大は, 電子遷移に関わる分子団にの み起こる。その結果, タンパク質においても, プローブ 光の波長を適切に選択することで，特定の一部の分子団 に由来する振動バンドのみのスペクトルが，部位特異的 
に高感度検出される，たとえば，可視光の波長領域のプ ローブ光をもちいると, 可視領域に吸収帯をもつ補欠分 子族の振動スペクトルが選択的に観測される。一方，プ ローブ光に紫外光の波長領域の光を選択すると, タンパ ク質部分に含まれる芳香族アミノ酸(トリプトファン・ チロシン・フェニルアラニン) 側鎖やペプチド結合に由 来する振動バンドが共鳴ラマン効果を受ける1)。さら に，ポンプ・プローブ法をもちいた時間分解測定と組み 合わせることにより, 光パルスをトリガーとしたタンパ ク質の化学反応において，「どの部位で，どのような時 間スケールで，どのように構造変化するのか? 」という 情報を得ることができる，時間分解能は，使用するレー ザーのパルス幅で決まる。このため, 時間分解共鳴ラマ ン分光法によって, ピコ秒からの高速タンパク質ダイナ ミクスを観測することが可能になる。

以下に, プローブ光の波長を紫外光の波長領域にした ときに得られる, タンパク質の紫外共鳴ラマンスペクト ルについて説明する。

\section{1 芳香族アミノ酸側鎖}

ラマン散乱の励起波長として, 210-250 nmの光を用い ると, 芳香族アミノ酸の側鎖芳香環の振動モードが観測 される ${ }^{1-3)}$. 芳香族アミノ酸残基は, 水素結合ネット ワークの一部をなしたり, 分子内電子移動を担ったりす るなど, タンパク質の生理機能に重要な役割を果たす。 このため, タンパク質ダイナミクス観測の際の, よいプ ローブとなる，側鎖芳香環の電子構造は, 分子の対称性

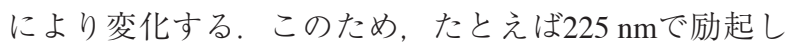
たタンパク質の紫外共鳴ラマンスペクトルでは, トリプ トファンの振動バンドが著しい強度増大を示す。一方 で，プローブ光の波長が，より長波長の $240 \mathrm{~nm}$ ，また は, より短波長の $210 \mathrm{~nm} ゙$ ある場合には, トリプト ファンのバンド強度が減少し, 代わってチロシンやフェ ニルアラニンのバンドの相対強度が増大する。適切なプ ローブ光の波長設定により, タンパク質中の特定部位に あるこれらの芳香族アミノ酸側鎖の選択的観測が可能と なる4).

芳香族アミノ酸側鎖の紫外共鳴ラマンスペクトルは, タンパク質内における残基周辺の環境変化の指標とな る. ラマンバンドの振動数については, トリプトファン では, $1550 \mathrm{~cm}^{-1}$ に現れるW3バンドは, インドール環の 配向角により振動数がシフトする $1620 \mathrm{~cm}^{-1}$ 付近に現れるY8aおよびY $8 \mathrm{~b}$ バンド, $1200 \mathrm{~cm}^{-1}$ 付近に現れるY7aバンドの振動数が, ヒドロキシル基の プロトン供与能や水素結合強度に敏感である。 また, $1180 \mathrm{~cm}^{-1}$ 付近に現れるY9aバンドの振動数は, 水素結合 強度が増加する場合や，ヒドロキシル基の構造歪みに対 して変化する6)。また，ラマンバンドの強度について は，トリプトファンでは，W3バンド，および $1000 \mathrm{~cm}^{-1}$, $870 \mathrm{~cm}^{-1}, 760 \mathrm{~cm}^{-1}$ にそれぞれ現れるW16, W17, W18バ ンドが, チロシンでは, Y8a, Y9a, およびY7aバンド が，側鎖周囲の環境変化に応じてその強度を変える。こ れは, 水素結合強度や疎水性相互作用の変化によって励
起プロフィールのシフトが起こるためで，これらのバン ド強度の変化を調べることによって，側鎖周囲の環境変 化を知ることができる7 $.1350 \mathrm{~cm}^{-1}$ 付近に現れるW7バ ンドは，トリプトファンダブレットと呼ばれている。観 測される2本のバンドの強度比が疎水性の指標となって いる2).

\section{2 ペプチド結合}

タンパク質の主鎖を形成するペプチド結合 (-CONH-) は，アミド振動とよばれるいくつかの特徵的な振動モー ドを示す ${ }^{8-10)}$. この振動数は，側鎖の構造の影響をほと んど受けず，ポリペプチド主鎖の構造をよく反映する. ペプチド結合のカルボニル基は，その $\pi-\pi$ *吸収帯を極 大波長190 nm付近にもつ。 したがって，ラマン散乱の 励起光の波長をこの吸収帯に合わせると，アミド振動 モードや,さらに炭素に結合した水素原子の面内変角 振動 $\left(\mathrm{C}_{\alpha}-\mathrm{H}\right.$ bend $)$ モードに起因するラマンバンドが強度 増大する。このため, これらのモードのバンド強度や振 動数は, タンパク質の二次構造の指標となる。ささざま なタンパク質のアミド振動バンドの共鳴ラマンスペクト ルの測定から, その振動数や強度との相関にもとついて 二次構造を決定できることが示されている ${ }^{11)}$. また，ア ミドIIIバンドおよび $\mathrm{C}_{\alpha}-\mathrm{H}$ bendバンドのスペクトルは, ポリペプチド鎖のコンフォメーション角に特に敏感であ り, 二次構造の決定に役立つことが知られている ${ }^{12)}$.

\section{3. 時間分解紫外共鳴ラマン分光計}

タンパク質ダイナミクスの検出には, 得られたラマン スペクトルの微小変化を解析する必要があるため, 測定 の高感度化が不可欠である。このため, さまざまな工夫 が必要となる。ここでは, 高感度かつ良質なスペクトル を得るために，筆者らが開発・改良を行ってきたピコ秒 時間分解紫外共鳴ラマン分光計を紹介し, 実験の留意点 を説明する. 紙面の都合上, 補欠分子族の構造ダイナミ クス観測に適した時間分解可視共鳴ラマン分光計につい ては，他の文献 ${ }^{13)} に$ 譲る。また，他のグループによる夕 ンパク質ダイナミクス観測のための時間分解紫外共鳴ラ マン分光計についても簡単に記す.

3.1 筆者らのグループによるピコ秒時間分解紫外共 鳴ラマン分光計

\section{1 .1 実験装置}

Fig. 1にシステムの概略図を示す。光源には，ピコ秒 チタンサファイア再生増幅システム(波長778-820 nm, エネルギー〜800 $\mu \mathrm{J}$, パルス幅〜 $2 \mathrm{ps,}$ 繰り返し $1 \mathrm{kHz}$ ) を用いている。レーザー出力の第二高調波を二つに分割 し, 種々の非線形光学効果による波長変換を行い, 調へ たいタンパク質に最適な波長のポンプ光およびプローブ 光を十分な強度で得る. ポンプ光の光路には光学遅延路 を配置している，その後，ポンプ光とプローブ光とを空 間的に重ねて, タンパク質試料溶液に後方 45 度の方向か ら集光する。試料からのラマン散乱光を主分光器により 


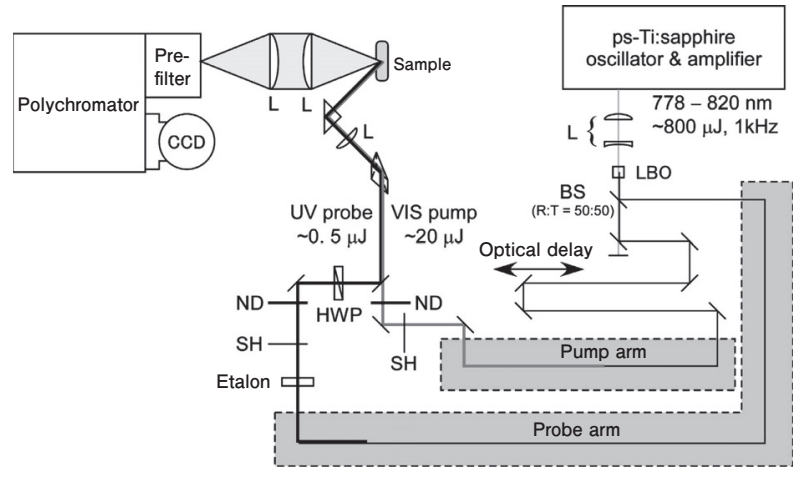

Fig. 1 Picosecond time-resolved ultraviolet resonance Raman apparatus. $\mathrm{LBO}=$ lithium triborate, $\mathrm{L}=$ lens, $\mathrm{BS}=$ beam splitter, $\mathrm{ND}=$ neutral density filter, $\mathrm{HWP}=$ half wave plate, $\mathrm{SH}=$ mechanical shutter.

分散し, CCD検出器によって検出する. 試料からの光 のうち, レイリー散乱光や蛍光成分は, 主分光器の前に 取り付けたプリズム分散型分光器により除去しておく. このようにして, 光反応によるタンパク質部分の構造変 化を, 紫外共鳴ラマンスペクトルの変化から観測する.

遅延時間の時間原点は, サンプル位置においてBBO結 晶をもちい, ポンプ光とプローブ光の差周波を発生させ ることで決定する.

ふたつの光パルスの相互相関時間幅は，3-4 psであ る. 得られるスペクトルのスペクトル分解能は, 約 $20 \mathrm{~cm}^{-1}$ である。これらの時間幅・スペクトル幅の関係 は, フーリエ変換限界に近いため, 本装置は時間分解振 動スペクトル測定においてほぼ極限にあるといえる。

\section{1 .2 実験の留意点}

(a) 光源

タンパク質ダイナミクス観測のため, 個々の部位にお ける振動スペクトルを高感度に得るには, 出力が安定し たプローブ光を紫外波長領域で広範かつ連続的に得なけ ればならない，芳香族アミノ酸側鎖およびペプチド結合 に由来する振動バンドを観測には，およそ200-250 nmの 範囲のプローブ光が必要になる。筆者らは, 時間分解ラ マン分光計の光源として, 最終出力のパルス幅が $2 \mathrm{ps}$ 程 度になるようなピコ秒再生増幅システムを利用してい る．このシステムでは, 光強度を増幅するために, パル ス伸長・増幅・圧縮を段階的に行う。システム内部の光 学部品の制約から, 部品交換を行わない場合の波長可変 範囲は, 778-820 nmに限られる。このため, 誘導ラマン 散乱と高調波・和周波発生を組み合わせた波長変換を行 い, 波長206-247 nmの範囲の連続した紫外光を, 安定で 十分な出力(試料位置において, $0.5 \mu \mathrm{J}$ 以上)で得る。 パ ルスレーザーと誘導ラマン散乱を利用した波長変換は, 時間分解共鳴ラマン測定において, 適当な波長のプロー ブ光を発生させる際によくもちいられている ${ }^{14)}$.これ は，波長変換した光が，振動スペクトルを測定するのに 十分狭いスペクトル幅の状態で発生するためである。誘 導ラマン散乱の発生は, プローブ光発生用の光を, 高圧 のメタンガスまたは水素ガスを封入したラマンシフタに
集光することで行う。このとき，入射光エネルギーか ら, メタン分子の全対称伸縮振動モード $\left(2916 \mathrm{~cm}^{-1}\right)$, または水素分子の伸縮振動モード $\left(4155 \mathrm{~cm}^{-1}\right)$ のエネル ギー分だけ低エネルギー側に, 1次ストークス誘導ラマ ン散乱光がコヒーレントに発生する。得られた1次ス トークス誘導ラマン散乱光の第二高調波発生から，波長 219-233 nm(メタン)および232-247 nm(水素)のプローブ 光が得られる (Fig. 2 (a))。 また, メタンのラマンシフ 夕による1次ストークス誘導ラマン散乱光とレーザー光 第二高調波の和周波発生により，波長206-218 nmのプ ローブ光が得られる (Fig. 2 (b)). 誘導ラマン散乱によ る波長変換において, ラマンシフタ内のガスの圧力や入 射する光の強度を適切に調整し, さらにエタロンを光路 上に配置することで, 得られるプローブ光のスペクトル 幅は2 $\mathrm{cm}^{-1}$ 程度に抑えることができる。

光反応によるスペクトル変化の検出効率を向上させる ためには, プローブ光発生用の波長変換とは独立に, 可 視光を吸収するさまざまな補欠分子族に対して，ポンプ 光の波長を吸収極大付近になるように調整する必要があ る、レーザー光第二高調波 (389-410 nm, Fig. 3 (a)), お よびメタンガスおよび水素ガスのラマンシフタの1次ス トークス誘導ラマン散乱光 (メタン: 439-465 nm, 水 素 : 464-494 nm, Fig. 3 (b))のほかに, 光パラメトリッ ク発生・増幅光 $(530-600 \text { nm, Fig. } 3 \text { (c) ) })^{15)}$ を使用し, 可 視光のほぼ全波長領域をカバーする。これにより，さま ざまなタンパク質(たとえば, へムタンパク質, イエ ロープロテイン, フラビンタンパク質, およびレチナー ルタンパク質など）の光応答による構造変化の高感度追 跡が可能になった.

波長変換にもちいた光パラメトリック発生・増幅につ いて簡単に説明する。光パラメトリック発生では, 温度 制御されたLBO結晶にレーザー光第二高調波を集光し, そのシグナル光を得る。あるレーザー発振波長に対する シグナル光の波長可変範囲は約 $20 \mathrm{~nm}$ であり, 結晶温度 を30-150 ${ }^{\circ} \mathrm{C}$ の間で変えて波長選択する. シグナル光と, LBO結晶を透過した残りのレーザー光を同軸でBBO結 晶に入射し, 増幅を行う。光パラメトリック発生・増幅 では，発生した光のスペクトル幅が約 $200 \mathrm{~cm}^{-1}$ と広がる ため, 単純にプローブ光にもちいることはできない. し かし, 光反応を効率よく起こすためには十分なスペクト

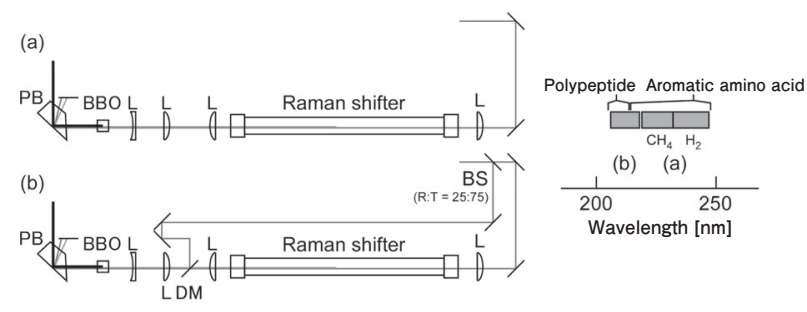

Fig. 2 Probe arm in Fig. 1. Left: Optical configuration for (a) the frequency doubling of the output of Raman shifter and (b) the frequency mixing of the output of Raman shifter and second harmonic of the laser output. $\mathrm{L}=$ lens, $\mathrm{BS}=$ beam splitter, $\mathrm{DM}=$ dichroic mirror, $\mathrm{BBO}=\beta$-barium borate, $\mathrm{PB}=$ Pellin-Broca prism. Right: Wavelength region of the probe pulse. 


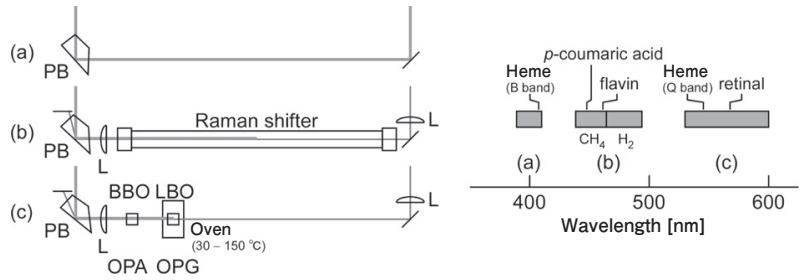

Fig. 3 Pump arm in Fig. 1. Left: Optical configuration for (a) the second harmonic of laser output, (b) the output of Raman shifter, and (c) the optical parametric generation $(\mathrm{OPG}) /$ amplification $(\mathrm{OPA})$. $\mathrm{L}=$ lens, $\mathrm{LBO}=$ lithium triborate, $\mathrm{BBO}=\beta$-barium borate, $\mathrm{PB}=$ Pellin-Broca prism. Right: Wavelength region of the pump pulsey.

ル幅である。また，サンプル位置におけるレーザー光強 度は, $10 \mu \mathrm{J}$ 以上あり, 十分な割合のタンパク質試料分 子に対して光反応を起こすことができる，

ピコ秒パルスの場合, 試料に照射される光電場は非常 に大きくなる。 このため, 使用する光の強度には十分な 注意が必要である。プローブ光の強度が大きすぎると, プローブ光強度とラマン散乱強度の線形性が崩れる, い わゆる「飽和現象」が起きる。 また，強いプローブ光によ る光反応で副生成物が生成し，そのスペクトルが観測さ れることがある ${ }^{16,17)}$. ポンプ光の強度が大きすぎると， タンパク質試料の誘電破壊や, 熱による変性・凝集が起 きるため, 試料が著しく劣化する。このようなことが起 こると，正しいダイナミクス観測が不可能になる。これ を避けるためには, 測定前に実験条件を十分に検討し, NDフィルター等による光強度の調節が必要である.

（b）ラマン散乱光の検出

タンパク質の良質な紫外共鳴ラマンスペクトルを得る ためには，試料からのレイリー散乱光や蛍光などによる 迷光を最大限に除去し，ラマン散乱光の強度ロスをでき るだけ最小限にとどめる必要がある。可視共鳴ラマン測 定では, ラマン散乱光を分散するシングル分光器の入射 スリットの直前に，ノッチフィルターやバンドパスフィ ルターなどの光学フィルターを配置して, 迷光除去を 行っている。一方, 紫外共鳴ラマン測定の場合, ラマン 散乱光のみが効率よく透過する光学フィルターがないた め, これを用いた迷光除去は困難である. このため, 光 透過率が高いリトロープリズムを用いた前置分光器 ${ }^{18)}$ を, シングル分光器の直前に配置し，プレフィルターと して使用する。

ラマン散乱光を検出するCCD検出器の量子効率も, 良質なスペクトルを得るための重要な要素である。 ラマ ン測定では, 光の照射面に対して酸化シリコン製の電極 が裏面に配置された背面照射型CCDをよく使用する。 さらに，素子上に反射防止コーティングを施すことで， 量子効率の向上を図っている。

(c) タンパク質試料

ラマン分光法は, 試料の形態による測定の制限が少な く，目的に合わせてこれを選択できる．タンパク質のラ
マンスペクトル測定においても例外ではなく，生体内に 近い環境で質のよいスペクトルを得ることができる。こ れは，ラマン分光法の大きな利点である.

パルスレーザーを用いた時間分解共鳴ラマン測定で は, パルスごとに光反応に対してフレッシュな試料への 光照射を常にしなくてはならない。このため，溶液状態 のタンパク質試料はフローさせる必要がある。筆者らが 使用しているフロー装置(ワイヤガイドノズル法 ${ }^{19}$ ), Fig. 4)について説明する。上部の液溜めにある試料は, 重力により2本のワイヤ間を落下し均質な液膜を形成す る。下部に流れた溶液は，ポンプにより送液され，再び 液溜めに戻る。溶液の循環により，少量のタンパク質試 料の繰り返し測定を行うことができる(本装置における1 回の積算の必要量は, 最小で $6 \mathrm{~mL}$ ある)。この装置の 光照射面にはガラスセルや石英セルがないため, エネル ギーが高いピコ秒パルス光を用いる測定に適している. また, 液膜の厚さは100-500 $\mu \mathrm{m}$ 程度に調節できるので, 試料中の光路長が短くなり, 紫外波長領域のタンパク質 の強い吸収による共鳴ラマン散乱の自己吸収効果を小さ く抑えられる利点がある。また，ごく少量の試料 $(1 \mathrm{~mL}$ 程度)や，ガス置換を行うために気密性が必要な場合は, 石英製NMRチューブを回転ホルダーに固定した回転セ ルをもちいている.

3.2 他のグループの時間分解紫外共鳴ラマン分光計 チタンサファイアレーザー発振器は，拈よそ700 $1000 \mathrm{~nm}$ の幅広い波長可変範囲を有する。このため, サ ブナノ秒以降のタンパク質ダイナミクス観測には，チタ ンサファイアレーザーの出力からの第四高調波を利用す る方法が，一般的に行われている（波長変換にもちいる $\mathrm{BBO}$ 結晶の位相整合条件により，とくに206 nm以下の 波長の光を得るためには，基本波と第三高調波の和周波 により第四高調波を得る $)^{20-23)}$ 。これらの装置は，時間 分解能が低下した分, スペクトル分解能が向上し, より 精度の高いタンパク質構造情報を得ることができる。

サブナノ秒時間分解測定において, Kuboらは, サブ ナノ秒チタンサファイア再生増幅システム(時間分解 能 $<0.5 \mathrm{~ns}$ ) の出力を光源とした, 時間分解ラマン分光計 を製作した ${ }^{20)}$ ，サブナノ秒パルスは，増幅時に光学部品 ヘダメージを与えないため, 再生増幅器内にパルス伸 長・圧縮器を必要としない。このため, チタンサファイ

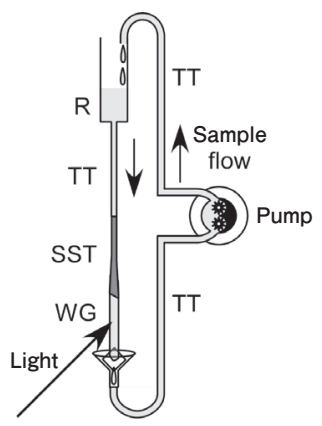

Fig. 4 Flowing system by a wire-guided nozzle. $\mathrm{R}=$ reservoir, $\mathrm{SST}=$ stainless steal tube, $\mathrm{WG}=$ wire guide, $\mathrm{TT}=$ Teflon tube . 
アレーザー発振器同様の幅広い波長可変範囲をもつ。こ の装置では, 二つに分割したレーザー光の第四高調波 (206-244 nm) および第二高調波(412-488 nm) を，それぞ れプローブ光とプローブ光にもちいている，遅延時間は 光学遅延をもちいて設定し, $-1 \mathrm{~ns}$ から+10 nsの時間分 解測定を行う。ナノ秒以降のタンパク質ダイナミクス測 定では，プローブ光には，Qスイッチレーザーで励起し たチタンサファイアレーザー発振器の出力の第四高調波 をもちいる ${ }^{21-23)}$ 。 ポンプ・プローブ測定には，2台のナ ノ秒レーザーをもちいて, 遅延時間はデジタルパルス発 生器で制御する。 ポンプ光の光源には, プローブ光用の レーザーとは独立したレーザーをもちいることができる ため, さまざまな波長のポンプ光を用いることが可能で ある。遅延時間の設定範囲は，レーザーの繰り返しによ り決定される.

このほかに, 高出力QスイッチNd: YAGレーザーの第 三高調波を光源にして, 水素のラマンシフタの5次アン チストークス誘導ラマン散乱光(波長 $204 \mathrm{~nm}$ )を, 紫外 プローブ光にもちいる方法も報告されている ${ }^{23)}$.

\section{4. 研究紹介}

筆者らはこれまでに, 本稿で説明したピコ秒時間分解 紫外共鳴ラマン分光計をもちいて，ミオグロビンのリガン ド光解離 ${ }^{24,25)}$, イエロープロテインの光反応初期過程 ${ }^{26)}$, グルコース酸化酵素の光誘起電子移動 27$)$ ，およびバクテ リオロドプシンのレチナール異性化に伴う構造ダイナミ クス ${ }^{28)}$ を観測してきた。詳細は参考文献 ${ }^{24-28)}$ を参照され たい。 ここでは, 紫外共鳴ラマンスペクトルの高感度測 定のための工夫を試行錯誤するきっかけとなった，イ工 ロープロテインの光反応初期過程の観測について簡単に 紹介する。

イエロープロテイン (Fig. 5 (a)) は, 紅色光合成細菌 中に含まれ，この細菌が示す負の走行性の光センサーで あると考えられている。 このタンパク質の発色団( $p$-ク マル酸)とタンパク質部分における構造ダイナミクスが, どのように連動しているのかを調べることを試みた。

Fig. 5 (b)に，イエロープロテインの光励起後 $3 \mathrm{ps}$ の時間 分解紫外共鳴ラマン差スペクトル (各スペクトルの上段) と, ポンプ光未照射状態の紫外共鳴ラマンスペクトル (各スペクトルの下段)を示す．プローブ光の波長を選択 することにより，部位特異的観測を行った，光照射後 $3 \mathrm{ps}$ のスペクトルは, $p$-クマル酸が電子励起状態にある ときのタンパク質構造を反映している，差スペクトルに 見られる負のバンドは，ポンプ光未照射状態のスペクト ルと比較して, バンド強度が減少していることを表して いる. 芳香族アミノ酸側鎖については, チロシンは Y8a，Y7a，およびY9aバンドに，トリプトファンはW3， W7，W16，およびW18バンドに明らかな強度減少が観 測された。ペプチド結合については，アミドIIIバンドに 強度減少が観測された。観測されたスペクトル変化か ら, 光照射 $3 \mathrm{ps}$ 後において, $p$-クマル酸とチロシン (Tyr42) 側鎖の間の水素結合の強化, $p$-クマル酸から離 (a)

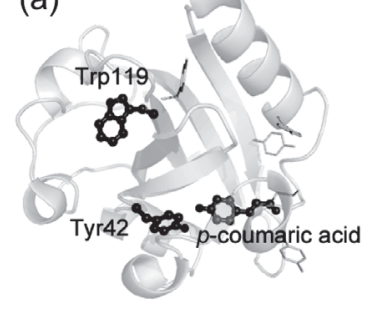

b)
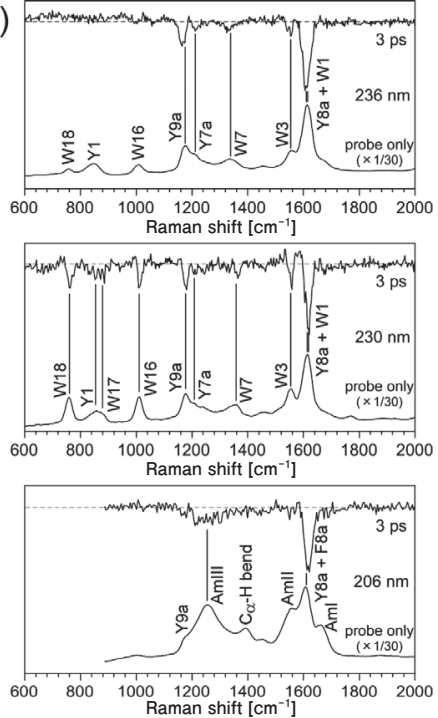

Fig. 5 (a) Molecular structure of photoactive yellow protein (PDB ID = 2PHY). (b) Time-resolved ultraviolet resonance Raman difference spectra and ultraviolet resonance Raman (probe-only) spectra of photoactive yellow protein in $10 \mathrm{mM}$ Tris- $\mathrm{HCl}$ buffer ( $\mathrm{pH}$ 7.0). Each probe-only spectrum has been divided by a factor of 30 . Probe and pump wavelengths: (top) 236 and $446 \mathrm{~nm}$, (middle) 230 and $460 \mathrm{~nm}$, (bottom) 206 and $439 \mathrm{~nm}$. Delay time: 3 ps.

れた位置にあるトリプトファン $(\operatorname{Trp} 119)$ 側鎖周辺の疎水 性の減少, 二次構造の変化，が起きたことがわかった。 光反応初期における二次構造变化は, 局所的に起こるこ とが予想される。このため， S/N比が非常に高いスペク トルの測定をしなければ，スペクトル変化の観測はきわ めて困難である。本研究により，ピコ秒時間領域におけ る二次構造変化に由来するスペクトル変化を初めて観測 することに成功した。

\section{5. まとめ}

この数年の研究を通じて, 時間分解共鳴ラマン分光法 をもちいたタンパク質ダイナミクス観測は,「ダイナミ クスを観測する」ことを研究目的に掲げる時期はすでに 終了したと考えられる. タンパク質の初期構造ダイナミ クスに関する情報は，赤外吸収スペクトルや円二色性ス ペクトルからも，共鳴ラマンスペクトルと相補的に得る ことができる。しかし，これらの分光手法は，溶質の他 の振動モードや溶媒の吸収, 試料からの蛍光や光散乱な どの影響を受けやすいため，実験条件に対する制約が多 い. 共鳴ラマン測定は，これらの制約が小さいため，生 理的な環境に近い状態でのタンパク質の構造情報をより 多く得られると期待できる。この利点を活かして，「ダ イナミクスがいかに機能と関連しているか」を検討し, タンパク質の機能発現のしくみを明らかにすることが, 次のタンパク質の分子科学研究の重要な課題となると考 えられる。 


\section{参考文献}

1) T. Kitagawa and S. Hirota: in Handbook of Vibrational Spectroscopy ed. J. M. Chalmers and P. R. Griffiths, Vol. 5 (John Wiley \& Sons, Chichester, 2002) p.3426

2) I. Harada and H. Takeuchi: in Spectroscopy of Biological Systems ed. R. J. H. Clark and R. E. Hester (John Wiley \& Sons, Chichester, 1986) p.113.

3) T. Kitagawa: Progress in Biophysics and Molecular Biology 58 (1992) 1.

4) R. P. Rava and T. G. Spiro: J. Phys. Chem. 89 (1985) 1856.

5) T. Miura, H. Takeuchi, and I. Harada: J. Raman Spectrosc. 20 (1989) 667.

6) H. Takeuchi, N. Watanabe, Y. Sato, and I. Harada: J. Raman Spectrosc. 20 (1989) 233.

7) Z. Chi and S. A. Asher: J. Phys. Chem. B 102 (1998) 9595.

8) T. Miyazawa, T. Shimanouchi, and S. Mizushima: J. Chem. Phys. 29 (1958) 611.

9) S. Krimm and J. Bandekar: Adv. Protein Chem. 38 (1986) 181.

10) R. A. Copeland and T. G. Spiro: Biochemistry 26 (1987) 2134.

11) Z. Chi, X. G. Chen, J. S. W. Holtz, and S. A. Asher: Biochem. 37 (1998) 2854.

12) S. A. Asher, A. Ianoul, G. Mix, M. N. Boyden, A. Karnoup, M. Diem, and R. Schweitzer-Stenner: J. Am. Chem. Soc. 123 (2001) 11775.

13）水谷 泰久：生物物理 47 (2007) 288 .

14) Y. Uesugi, Y. Mizutani, S. G. Kruglik, A. G. Shvedko, V. A.
Orlovich, and T. Kitagawa: J. Raman Spectrosc. 31 (2000) 339.

15) Y. Uesugi, Y. Mizutani, and T. Kitagawa: Rev. Sci. Instrum. 68 (1997) 4001

16) S. A. Asher, M. Ludwig, and C. R. Johnson: J. Am. Chem. Soc. 108 (1986) 3186.

17) C. R. Johnson, M. Ludwig, and S. A. Asher: J. Am. Chem. Soc. 108 (1986) 905.

18) S. Kaminaka and R. A. Mathies: Appl. Spectrosc. 52 (1998) 469.

19) M. J. Tauber, R. A. Mathies, X. Chen, and S. E. Bradforth: Rev. Sci. Instrum. 74 (2003) 4958.

20) M. Kubo, T. Uchida, S. Nakashima, and T. Kitagawa: Appl. Spectrosc. 62 (2008) 30.

21) X. Zhao, R. Chen, C. Tengroth, and T. G. Spiro: Appl. Spectrosc. 53 (1999) 1200.

22) X. Zhao, C. Tengroth, R. Chen, W. R. Simpson, and T. G. Spiro: J. Raman Spectrosc. 30 (1999) 773.

23) S. Bykov, I. Lednev, A. Ianoul, A. Mikhonin, C. Munro, and S. A Asher: Appl. Spectrosc. 59 (2005) 1541.

24) A. Sato and Y. Mizutani: Biochem. 44 (2005) 14709.

25) A. Sato, Y. Gao, T. Kitagawa, and Y. Mizutani: Proc. Natl. Sci. Acad. Sci. USA 104 (2007) 9627.

26) M. Mizuno, N. Hamada, F. Tokunaga, and Y. Mizutani: J. Phys. Chem. B 111 (2007) 6293.

27) A. Fujiwara and Y. Mizutani: J. Raman Spectrosc. 39 (2008) 1600.

28) M. Mizuno, M. Shibata, J. Yamada, H. Kandori, and Y. Mizutani: J. Phys. Chem. B 113 (2009) 12121.

レーザーワード

ラマン分光法 (Raman spectroscopy)

ラマン分光法では，分子に単色光を照射し，その散乱 光を測定する. 散乱光の中には, 照射した光の振動数 $\left(E_{\mathrm{i}}\right)$ とは異なる振動数 $\left(E_{\mathrm{s}}\right)$ を持つものがあり, 両者の差 $\left(E_{\mathrm{i}}-E_{\mathrm{s}}\right.$, これをラマンシフトとよぶ) は振動準位間のエ ネルギー差と等しい.したがって, 散乱光のスペクトル から振動スペクトルを得ることができる。これがラマン
散乱スペクトル(略してラマンスペクトル)である。スペ クトルからは，主に分子構造に関する情報が得られる. また, 照射する光の振動数が分子の電子遷移の振動数に 近づくと, 散乱光の強度が非常に強くなる。この現象を 共鳴ラマン効果とよび，得られる振動スペクトルを共鳴 ラマンスペクトルとよぶ. (水谷泰久) 